of the College of Technologists and to those at present studying for these awards. The statement reaffirms the Council's belief in the value of the sandwich course leading to the Diploma in Technology, and urges that all possible steps should be taken to ensure the further development of sandwich courses. It also believes that action should be taken to make certain that academic resources, the supply of industrial training places, and the standard of industrial training together meet the nation's needs. For this purpose the Council considers that consultations should be held as early as possible between the various organizations interested in sandwich courses, and in this connexion it refers to the colleges of technology, the technical colleges, industry, the Council for National Academic Awards and the industrial training boards proposed in the Bill now before Parliament. The Council also urges the Council for National Academic Awards and the colleges to continue to develop the concept of programmes of research work in collaboration with colleges and indus. trial organizations embodied in the award of Membership of the College of Technologists.

\section{Assembly-line Inspection in Industry}

WIDE differences in judgments of quality are often made about the same batch of articles coming off an assembly line, not only by different inspectors, but by the same man at different times. In a booklet issued by the Department of Scientific and Industrial Research entitled Inspection and Human Efficiency, R. M. Belbin suggests steps which might be taken to improve inspection methods (No. 4 in the series Ergonomics for Industry. Obtainable free of charge from the Library, Department of Scientific and Industrial Research, State House, High Holborn, London, W.C.1). Inadequate illumination or poor layout are usually at the root of the problem. Often the visual acuity of the inspector is not even considered and the assembly line moves at such a speed that it is impossible for him to do his job thoroughly. Inspectors have special problems and their integrity and human relationships are often strained to the limit and their status uncertain. It is understandable for them to feel that if they find too few faults it will endanger their own jobs. Similarly, where piece-rate work is being carried out, if they set too stringent a standard they get complaints from their colleagues. They tend, therefore, to maintain a constant rejection rate, items of an acceptable standard being rejected when the plant is running well, some items of a low quality being passed when it is not. Standards are often low because there is no satisfactory criterion for assessing the efficiency of inspection. Control of inspection tends to look like a form of 'spying' and it is not unnaturally resented as such. The booklet outlines a seven-point plan for improving inspection methods in British industry and calls for the application of ergonomic data to the problem of raising the standard of industrial products.

\section{The British Hat and Allied Feltmakers Research Associa- tion}

THE sixteenth annual report of the Director of Research of the British Hat and Allied Feltmakers Research Association for the year ended August 1963 includes the usual list of publications, staff and members of Council and Committees (Pp. 22. Audenshaw, Manchester: British Hat and Allied Foltmakers Research Association, 1963). An outstanding feature of the year was the discovery of a new carroting agent which confines reaction to the disulphide linkages, retaining the intrinsic strength of the fibre and giving felt of higher quality. Use of dimethyl sulphoxide as an aid to felting was examined in groater detail, and work on the tochnology of forming started with a survey of the operating conditions of the forming machines used by fur-felt firms. Considerable progress was achieved in applying the faster types of dyes to both wool and fur-felt by a selective choice of levelling agents at appropriate concentrations in conjunction with a controlled temperature-time cycle of dyeing. An investigation of hat finishing procedures is being made on Doran machines to determine the effect of choice of paper, and a review of the felt quality indexes (T.D.M.) based on quality tests for 1961 has been completed.

\section{The United States National Museum}

THE director of the U.S. National Museum in his report for the year ending June 30, 1963, mentions the especially noteworthy accomplishments of the reopening of the three large halls of modernized exhibits in the Museum of Natural History and the start of the installation of exhibits in the new Museum of History and Technology (Pp. viii + 226. Washington, D.C.: Government Printing Office, 1964). In the Department of Archæology a section of six units explains the objects and dating methods now used, and other exhibits show characteristic weapon points and other artefacts of the Folsom, Agate Basin and other big-game hunters of 7,000-10,000 years ago. Within each region, cultural variations through time are revealed in representative artefacts and art work. A lifesized model of a blue whale has been installed in the Zoology Department. The construction of a desert life group in the Botany Department has been based on field work carried out by the Museum staff. In the Geology Department the central figure is a gigantic Diplodocus and a unique specimen of the skeleton of Thescelosaurus, which was a small, agile, plant-eating dinosaur. Special exhibits show methods of classifying the dinosaurs and the various ways in which they adapted themselves to their environment. The dinosaurian remains in this Museum are of historic as well as scientific interest, for many were collected between 1870 and 1895. The report is profusely illustrated.

\section{The National Museum of Wales, Cardiff}

THE outstanding item of interest in the report of the National Museum of Wales for 1962-63 is that the building of the West Wing has proceeded throughout the year (Pp. 91 +6 plates. Cardiff: National Museum of Wales, 1963). Although preparations for its occupation are being made, it will be a considerable time after the building is handed over before it can be opened to the public. In the Department of Geology the reorganization of the reserve and study collections has been continued, while in the Department of Botany the emphasis has been on modernization and expansion. Building operations have interfered with normal exhibition work in the Department of Zoology, and in the Department of Archæology modernization of exhibits has continued in the later Prehistoric gallery. Several loan exhibitions have been staged by the Department of Art. The Southgate Toll-house (built 1771) at Penparcau, Aberystwyth, was accepted by the Welsh Folk Museum at St. Fagans. Another recent and important acquisition consists of the old cockpit from Denbigh.

\section{The American Academy of Arts and Sciences}

A BRochure recently issued by the American Academy of Arts and Sciences describes the origins of the Academy, which was incorporated on December 15, 1779, its membership and publications, its research funds and medals (which include the Rumford Fund, the Emerson-Thoreau Medal and the Francis Amory Prizes) as well as the Academy's contribution to the contemporary world (The American Academy of Arts and Sciences: Descriptive Brochure. Pp. 19 (8 plates). Boston: The American Academy of Arts and Sciences, 1963). The latter section emphasizes that the Academy is not departmentalized. that it does not hold meetings for the several branehes of learning, and that its policy is based on the conviction that fruitful intercourse between the branches of learning, rather than the advancement of the separate disciplines, is an increasingly acute need of the times. 